\title{
The effect of corporate geographic location on over-investment
}

\author{
Xintong Shi*,Wenbin Bao \\ Nanjing University of Science and Technology, China \\ *Corresponding author: Xintong Shi, master degree candidate, shixintong2017@qq.com
}

\begin{abstract}
This paper aims to shed light on the effect of a firm's geographic location on its over-investment by using different location variables based on a sample of 1936 Chinese listed firms spanning from 2007 to 2016. We find that remotely located firms have higher level of over-investment. Remotely located firms with more free cash flow face severer over-investment problem. In further research, we examine whether institutional investors can mitigate remote firms' over-investment. However, we find that institutional investors have no governance effect on remote firms' over-investment.
\end{abstract}

Key words: geographic location; over-investment; Institutional investors; information asymmetry; agency problem

\section{Introduction}

Previous studies show that firm characteristics impact over-investment, however, they neglect a very obvious characteristic of firms: location. In remote areas, it is harder for investors to oversee listed firms, which deteriorates agency problems. Severe agency problems in remote firms impact firm's behavior. We consider firm's location has significant impact on over-investment according to the previous studies. In this paper, we examine the impact of location on firm over-investment and the influence of free cash flow on the impact of location on firm over-investment.

Remotely located firms face severer information asymmetry and agency problems, which influences its cash holding decisions and financing capability (Boubaker et $a l^{1}{ }^{1}$ ). Richardson(2006) ${ }^{2}$ argues free cash flow and financing constraint are responsible for firm's over-investment. Xinquan Yang and Yumei $\mathrm{Fu}^{3}$ find firms located in non-center cities hold more cash and tend to invest more. These firms suffer high financing costs and financing constraint because big banks are usually unwilling to offer loans to them due to lack of information (Arena $\left.{ }^{4}\right)$. Without enough external funds, remote firms attempt to maintain internal funds. Cheaper internal funds may lead to over-investment (Myers and Majluf, ${ }^{5} 1984$ ). Based on the above analysis, we find the routes that location influences over-investment: On one hand, remote firms face severer information asymmetry and agency problems. Managers or controlling shareholders are more likely to over -invest when regulation is limited by location. Free cash flow can intensify over-investment. On the other hand, financing 
constraint caused by information disadvantage of remotely located firms pushes these firms to maintain more internal funds, they invest more because of low cost.

There are different ideas about the governance effect of institutional investors. Some argue that institutional investors have no positive effect on the corporate performance (Faccio and Lasfer, $^{6}$ 2000). On the contrary, Shleifer and Vishny(1986) ${ }^{7}$ argue institutional investors have ability to oversee managers and are willing to do that. Whether institutional investors can mitigate remote firms' over-investment is another part of our study.

Xingquan yang and Yumei fu(2016) make a primary study on the impact of firm's location on the over-investment. Because their study does not focus on over-investment, they don't demonstrate sufficient theory, mechanism and explanation about the impact of firm's location on over-investment. Our study is motivated from their research but different from their work in the following aspects: First, we analyze the mechanism that location influences over-investment and find the influence routes. Second, we use two standards to distinguish remote areas and center areas. Last, we take the governance effect of institutional investors into consideration.

The rest part of this paper is structured as follows. Section 2 presents variables, data and models. Section 3 presents the main results. We conclude our results in section 4.

\section{Variables, models and data}

\subsection{Variables and models}

The dependent variable in our research is over-investment. We refer to Richardson(2006) to estimate over-investment. We directly use residual of model in Richardson(2006) as the estimate of over-investment which is labeled as Overi in the following regression results. Yanchao Wang(2009) ${ }^{8}$ uses the same measure of over-investment.

To examine the impact of firm's location on over-investment, we use the following model.

overi $_{i, t}=\alpha+\beta_{1}$ Location $_{i, t}+\beta_{2}$ Lev $_{i, t}+\beta_{3}$ Board $_{i, t}+\beta_{4}$ State $_{i, t}+\beta_{5}$ Own $_{i, t}+\beta_{6}$ Roa $_{i, t}+\beta_{7}$ Size $_{i, t}$

$+\beta_{8}$ Growth $_{i, t}+$ Yeardummy + Industrydummy $+\varepsilon$

In this model, Overi indicates over-investment, Growth is proxied by sales revenue growth, Lev indicates leverage which is calculated by total debt divided by total assets. Cash indicates cash holdings computed as cash plus short-term investment or financial assets to trade divided by lagged assets, Age indicates the number of years from firms IPO, Size is natural log value of book value of total assets, Ret is the market adjusted return as in Huili Zhang and Zhengfei $\mathrm{Lu}(2012)^{9}$, Yeardummies and Industrydummies are dummy variables to control year effect and industry effect. Board indicates the ratio of independent directors in the board, Own indicates the ownership concentration measured by the percentage of shares held by the greatest shareholders, Roa indicates the return of assets, State is the state owned firms dummy.

We use three proxies as location variables: Nonc, Noncp and Distance. If firm's registered location is not in center cities, Nonc equals 1 and 0 otherwise. If firm's location is not in center 
provinces, Noncp equals 1and 0 otherwise. According to " blue book of urban competitiveness” and “ the blue book of provincial competitiveness” in year 2015 published by Chinese Academy of Social Science, we choose top 20 cities as center cities and top 10 provinces including 3 municipalities as center provinces. Previous studies usually use cities to distinguish remote areas and center areas. However, we consider this standard ignores relation between cities. Some median cities or small cities also have strong economic power and high popularity because they are near center cities. Nevertheless, they are classified into remote areas. Cites in the same province have similar economic power, cultural development level and political development level. So, we also use province as another standard to distinguish remote areas. We gauge the distance of firm's location from the nearest center city as a metric of its location using the model from Coval and Moskowitz (1999) ${ }^{10}$.

For further research, we try to test the impact of free cash flow and institutional investors. We design model(2) and model(3).

$$
\begin{aligned}
& \text { overi }_{i, t}=\alpha+\beta_{1} \text { Location }_{i, t}+\beta_{2} \text { Fcf }_{i, t}+\beta_{3} \text { Location }^{*} \text { Fcf }_{i, t}+\beta_{4} \text { Lev }_{i, t}+\beta_{5} \text { Board }_{i, t}+\beta_{6} \text { State }_{i, t} \\
& +\beta_{7} \text { Own }_{i, t}+\beta_{8} \text { Roa }_{i, t}+\beta_{9} \text { Size }_{i, t}+\beta_{10} \text { Growth }_{i, t}+\text { Yeardummy } \text { Industrydummy }+\varepsilon \\
& \text { overi }_{i, t}=\alpha+\beta_{1} \text { Location }_{i, t}+\beta_{2} \text { Ins }_{i, t}+\beta_{3} \text { Location }^{*} \text { Ins }_{i, t}+\beta_{4} \text { Fcf }_{i, t}+\beta_{5} \text { Lev }_{i, t}+\beta_{6} \text { Board }_{i, t}+\beta_{7} \text { State }_{i, t} \\
& +\beta_{8} \text { Own }_{i, t}+\beta_{9} \text { Roa }_{i, t}+\beta_{10} \text { Size }_{i, t}+\beta_{11} \text { Growth }_{i, t}+\text { Yeardummy }_{\text {Industrydummy }}+\varepsilon
\end{aligned}
$$

In model(2), Fcf indicates free cash flow computed as net cash flows from operating activities minus normal investment from model in Richardson(2006). In model(3), Ins indicates the percentage of shares held by institutional investors.

\subsection{Data}

The initial samples encompass all listed firms in shanghai exchange and shenzhen exchange during 2007-2016. Distance between firm's location and the nearest city is manually calculated, other data are from CSMAR database and RESSET database. We remove following samples: (1)Financial listed firms; (2)Firms issuing $\mathrm{H}$ or $\mathrm{B}$ shares; (3)ST or ST*samples; (4)Abnormal samples, such as assets less than 0; (5)Samples with missing data in key indicators. All constant variables are winsorized at the $1 \%$ and $99 \%$ percentile level.

\section{Results and robustness checks}

\subsection{Results}

Table1 shows the effect of location on over-investment. The t-Statistics is reported in parentheses. Significance at $1 \%, 5 \%$ and $10 \%$ is denoted with $* * *$, ** and * respectively, the same blew. The results show that the location variables are positively related to over-investment. It is obvious that firms located in non-center cities or non-center provinces have higher over-investment. The results also show that firms face more over-investment when they are far away from center cities. The findings provide evidence that remote firms face higher agency costs arising from additional hurdles in the regulation of managers and 
Table 1 - The effect of location on over-investment

\begin{tabular}{|c|c|c|c|c|c|c|}
\hline Variables & (1) & (2) & (3) & (4) & (5) & (6) \\
\hline Nonc & $\begin{array}{c}0.0015 \\
(1.5395)\end{array}$ & & & $\begin{array}{c}0.0015 \\
(1.5618)\end{array}$ & & \\
\hline Noncp & & $\begin{array}{l}0.0025 * * \\
(2.4876)\end{array}$ & & & $\begin{array}{l}0.0024 * * \\
(2.3821)\end{array}$ & \\
\hline Distance & & & $\begin{array}{l}0.0006 * * \\
(2.5044)\end{array}$ & & & $\begin{array}{l}0.0007 * * \\
(2.5181)\end{array}$ \\
\hline State & $\begin{array}{c}-0.0004 \\
(-0.3429)\end{array}$ & $\begin{array}{c}-0.0008 \\
(-0.7597)\end{array}$ & $\begin{array}{c}-0.0004 \\
(-0.3759)\end{array}$ & & & \\
\hline Own & $\begin{array}{l}-0.0025 \\
(-0.7719)\end{array}$ & $\begin{array}{l}-0.0023 \\
(-0.7074)\end{array}$ & $\begin{array}{l}-0.0023 \\
(-0.7301)\end{array}$ & & & \\
\hline Lev & $\begin{array}{l}0.0180 * * * \\
(5.8857)\end{array}$ & $\begin{array}{l}0.0179 * * * \\
(5.8741)\end{array}$ & $\begin{array}{l}0.0178 * * * \\
(5.8411)\end{array}$ & $\begin{array}{c}0.0178 * * * \\
(5.8525)\end{array}$ & $\begin{array}{c}0.0176 * * * \\
(5.8119)\end{array}$ & $\begin{array}{c}0.0176 * * * \\
(5.8037)\end{array}$ \\
\hline Board & $\begin{array}{c}0.0000 \\
(0.7496)\end{array}$ & $\begin{array}{c}0.0000 \\
(0.7778)\end{array}$ & $\begin{array}{c}0.0000 \\
(0.7686)\end{array}$ & & & \\
\hline Roa & $\begin{array}{l}0.0681 * * * \\
(7.1162)\end{array}$ & $\begin{array}{c}0.0687 * * * \\
(7.1811)\end{array}$ & $\begin{array}{c}0.0686 * * * \\
(7.1676)\end{array}$ & $\begin{array}{c}0.0678 * * * \\
(7.1175)\end{array}$ & $\begin{array}{c}0.0686 * * * \\
(7.1988)\end{array}$ & $\begin{array}{c}0.0683 * * * \\
(7.1730)\end{array}$ \\
\hline Size & $\begin{array}{l}0.0011 * * \\
(2.0382)\end{array}$ & $\begin{array}{l}0.0012 * * \\
(2.1277)\end{array}$ & $\begin{array}{l}0.0011 * * \\
(2.0589)\end{array}$ & $\begin{array}{l}0.0010 * \\
(1.8587)\end{array}$ & $\begin{array}{l}0.0010 * \\
(1.8718)\end{array}$ & $\begin{array}{l}0.0010^{*} \\
(1.8808)\end{array}$ \\
\hline Growth & $\begin{array}{c}0.0051 * * * \\
(4.7320)\end{array}$ & $\begin{array}{c}0.0050 * * * \\
(4.6794)\end{array}$ & $\begin{array}{l}0.0051 * * * \\
(4.7247)\end{array}$ & $\begin{array}{c}0.0051 * * * \\
(4.7546)\end{array}$ & $\begin{array}{c}0.0051 * * * \\
(4.7220)\end{array}$ & $\begin{array}{c}0.0051 * * * \\
(4.7486)\end{array}$ \\
\hline Constant & $\begin{array}{c}-0.0339 * * * \\
(-2.6118)\end{array}$ & $\begin{array}{c}-0.0353 * * * \\
(-2.7143)\end{array}$ & $\begin{array}{c}-0.0343 * * * \\
(-2.6466)\end{array}$ & $\begin{array}{c}-0.0310^{* *} \\
(-2.4408)\end{array}$ & $\begin{array}{l}-0.0317 * * \\
(-2.4921)\end{array}$ & $\begin{array}{c}-0.0314 * * \\
(-2.4723)\end{array}$ \\
\hline Observations & 13,614 & 13,614 & 13,614 & 13,614 & 13,614 & 13,614 \\
\hline $\begin{array}{c}\text { Industry and } \\
\text { Year }\end{array}$ & controlled & controlled & controlled & controlled & controlled & controlled \\
\hline Adj.R ${ }^{2}$ & 0.00864 & 0.00891 & 0.00892 & 0.00875 & 0.00899 & 0.00904 \\
\hline F value & 4.953 & 5.082 & 5.084 & 5.451 & 5.573 & 5.597 \\
\hline
\end{tabular}

Table 2 - The impact of free cash flow and institutional investors on remotely located firms

\begin{tabular}{|c|c|c|c|c|c|c|}
\hline Variables & (1) & (2) & (3) & (4) & (5) & (6) \\
\hline Nonc & $\begin{array}{l}0.0018^{*} \\
(1.9151)\end{array}$ & & & $\begin{array}{c}-0.0005 \\
(-0.4125)\end{array}$ & & \\
\hline Fcf & $\begin{array}{c}0.0453 * * * \\
(5.8668)\end{array}$ & $\begin{array}{c}0.0570 * * * \\
(9.0981)\end{array}$ & $\begin{array}{c}0.0436 * * * \\
(5.8173)\end{array}$ & $\begin{array}{c}0.0607 * * * \\
(11.3865)\end{array}$ & $\begin{array}{c}0.0607 * * * \\
(11.3763)\end{array}$ & $\begin{array}{l}0.0608 * * * \\
(11.3957)\end{array}$ \\
\hline Ins & & & & 0.0022 & $0.0052 *$ & 0.0016 \\
\hline Nonc*Fcf & $\begin{array}{c}0.0269 * * * \\
(2.7017)\end{array}$ & & & (0.5835) & (1.6957) & \\
\hline Nonc*Ins & & & & $\begin{array}{l}0.0113 * * \\
(2.2260)\end{array}$ & & \\
\hline noncp & & $0.0027 * * *$ & & & 0.0008 & \\
\hline Noncp ${ }^{*}$ Fcf & & $\begin{array}{c}(2.6180) \\
0.0111 \\
(1.0388)\end{array}$ & & & $(0.6126)$ & \\
\hline Noncp*Ins & & & & & $\begin{array}{l}0.0101 * \\
(1.8549)\end{array}$ & \\
\hline Distance & & & $\begin{array}{c}0.0008 * * * \\
(2.9254)\end{array}$ & & & $\begin{array}{c}-0.0000 \\
(-0.0107)\end{array}$ \\
\hline Disatance*Fcf & & & $\begin{array}{c}0.0087 * * * \\
(3.1762)\end{array}$ & & & \\
\hline Distance*Ins & & & & & & $\begin{array}{c}0.0035 * * \\
(2.5746)\end{array}$ \\
\hline State & $\begin{array}{c}-0.0012 \\
(-1.1095)\end{array}$ & $\begin{array}{c}-0.0016 \\
(-1.4995)\end{array}$ & $\begin{array}{c}-0.0012 \\
(-1.1545)\end{array}$ & $\begin{array}{c}-0.0012 \\
(-1.1315)\end{array}$ & $\begin{array}{c}-0.0017 \\
(-1.5526)\end{array}$ & $\begin{array}{c}-0.0012 \\
(-1.1651)\end{array}$ \\
\hline Own & $\begin{array}{c}-0.0029 \\
(-0.9008)\end{array}$ & $\begin{array}{l}-0.0028 \\
(-0.8777)\end{array}$ & $\begin{array}{l}-0.0028 \\
(-0.8756)\end{array}$ & $\begin{array}{l}-0.0029 \\
(-0.9221)\end{array}$ & $\begin{array}{l}-0.0028 \\
(-0.8640)\end{array}$ & $\begin{array}{l}-0.0029 \\
(-0.9024)\end{array}$ \\
\hline Lev & $\begin{array}{c}0.0171 * * * \\
(5.6462)\end{array}$ & $\begin{array}{c}0.0170 * * * \\
(5.6110)\end{array}$ & $\begin{array}{c}0.0169 * * * \\
(5.5839)\end{array}$ & $\begin{array}{c}0.0174 * * * \\
(5.7233)\end{array}$ & $\begin{array}{c}0.0172 * * * \\
(5.6728)\end{array}$ & $\begin{array}{c}0.0172 * * * \\
(5.6829)\end{array}$ \\
\hline Board & $\begin{array}{c}0.0001 \\
(1.2674)\end{array}$ & $\begin{array}{c}0.0001 \\
(1.3084)\end{array}$ & $\begin{array}{c}0.0001 \\
(1.2828)\end{array}$ & $\begin{array}{c}0.0001 \\
(1.3551)\end{array}$ & $\begin{array}{c}0.0001 \\
(1.3804)\end{array}$ & $\begin{array}{c}0.0001 \\
(1.3679)\end{array}$ \\
\hline Roa & $\begin{array}{c}0.0323 * * * \\
(3.2263)\end{array}$ & $\begin{array}{c}0.0334 * * * \\
(3.3290)\end{array}$ & $\begin{array}{c}0.0328 * * * \\
(3.2747)\end{array}$ & $\begin{array}{c}0.0284 * * * \\
(2.8226)\end{array}$ & $\begin{array}{c}0.0298 * * * \\
(2.9607)\end{array}$ & $\begin{array}{c}0.0290 * * * \\
(2.8767)\end{array}$ \\
\hline Size & $\begin{array}{c}0.0014 * * * \\
(2.5951)\end{array}$ & $\begin{array}{c}0.0015 * * * \\
(2.6986)\end{array}$ & $\begin{array}{c}0.0014 * * * \\
(2.6227)\end{array}$ & $\begin{array}{l}0.0013 * * \\
(2.3802)\end{array}$ & $\begin{array}{l}0.0014 * * \\
(2.4656)\end{array}$ & $\begin{array}{l}0.0013 * * \\
(2.3962)\end{array}$ \\
\hline Growth & $\begin{array}{c}0.0060 * * * \\
(5.5710)\end{array}$ & $\begin{array}{c}0.0059 * * * \\
(5.5306)\end{array}$ & $\begin{array}{c}0.0059 * * * \\
(5.5464)\end{array}$ & $\begin{array}{c}0.0059 * * * \\
(5.5271)\end{array}$ & $\begin{array}{c}0.0058 * * * \\
(5.4231)\end{array}$ & $\begin{array}{c}0.0059 * * * \\
(5.5253)\end{array}$ \\
\hline Constant & $\begin{array}{c}-0.0417 * * * \\
(-3.2270)\end{array}$ & $\begin{array}{c}-0.0437 * * * \\
(-3.3734)\end{array}$ & $\begin{array}{c}-0.0421 * * * \\
(-3.2580)\end{array}$ & $\begin{array}{c}-0.0397 * * * \\
(-3.0689)\end{array}$ & $\begin{array}{c}-0.0412 * * * \\
(-3.1779)\end{array}$ & $\begin{array}{c}-0.0399 * * * \\
(-3.0864)\end{array}$ \\
\hline $\begin{array}{c}\text { Industry and } \\
\text { Year }\end{array}$ & controlled & controlled & controlled & controlled & controlled & controlled \\
\hline Observations & 13,614 & 13,614 & 13,614 & 13,614 & 13,614 & 13,614 \\
\hline Adj. $R^{2}$ & 0.0183 & 0.0181 & 0.0187 & 0.0188 & 0.0190 & 0.0192 \\
\hline $\mathrm{F}$ & 8.921 & 8.848 & 9.127 & 8.901 & 8.978 & 9.076 \\
\hline
\end{tabular}


controlling shareholders. Firm size, growth opportunities, profitability and leverage have significantly positive effect on over-investment, the results are consistent with Xingquan Yang and Yumei $\mathrm{Fu}(2016)$.

We test the effect of location on the over-investment when taking free cash flow problem into consideration. Column (1), (2) and (3) in table2 are results of free cash flow conflicts. The results show the effect of location on the over-investment is deepened by free cash flow. Free cash flow significantly affects listed firms in non-center cities. More free cash flow supports managers or controlling shareholders to invest more.

Institutional investors play an important role in monitoring firm performance according to Hutchinson et al.(2015) ${ }^{11}$. However, we find contrasting evidence in our study that institutional investors have an adverse effect on firm investment efficiency. Column (4), (5) and (6) in table2 show the test of governance effect of institutional investors. It is clear that higher institutional ownership is associated with greater over-investment. Firms located in remote areas don't benefit from institutional investors. This means institutional investors are not always active regulators. The characteristics of institutional investors are complex. Institutional investors may cause agency problems, because they are agents too and they don't aim to maximum shareholders' wealth (Black, 1992) ${ }^{12}$.

\subsection{Robustness checks}

We do several robustness tests to check our results. First, we substitute ratio of sales income with TobinQ as the proxy of growth opportunities. Second, to remove the effect of estimate of over-investment, we use a new model according to Biddle et al. (2009) ${ }^{13}$ to estimate over-investment. Third, we remove samples from 2007 to 2009 to avoid the effect of financial crisis. Our main results hold in robustness checks. For the limit of pages, we do not report results of robustness checks.

\section{Conclusions}

We find that firms located in non-center cities or non-center provinces have greater over-investment. Over-investment increases when the distance between listed firms and nearest center city increases. Free cash flow can reinforce the impact of location on the over-investment. Institutional investors have no governance effect on the impact of location on over-investment, they even push over-investment into a higher level. Our results are robust to alternative model of estimating firm over-investment and to different ranges of samples. Further work could try to classify institutional investors into different kinds and test their impact on the effect of location on over-investment.

\section{References}

1. S. Boubaker, I. Derouiche, M. Lasfer, Geographic location, excess control rights, and cash holdings, J. International Review of Financial Analysis. 42 (2015) 24-37. 
2. S. Richardson, Over-investment of free cash flow, J. Review of Accounting Studies. 11 (2006) 159-189.

3. Y. Xingquan, F. Yumei, Geographic location and firm's cash holdings_evidence from Chinese listed firms, J. Dong Yue Tribune. 37 (2016) 69-80.

4. P. M. Arena, M. Dewally, Firm location and corporate debt, J. Journal of Banking and Finance, 36 (2012) 1079-1092.

5. S. Myers, N. Majluf, Corporate financing and investment when firms have information shareholders do not have, J. Journal of Financial Economics. (1984) 187-221.

6. M. Faccio, M. A. Lasfer, Do occupational pension funds monitor companies in which they hold large stakes, J. Journal of Corporate Finance. 6 (2000) 71-110.

7. R. Morck, A. Shleifer, R. W. Vishny, Management ownership and corporate performance: an Empirical Analysis, J. Social Science Electronic Publishing. 4 (1986) 1441-1453.

8. W. Yanchao, Financial constraints, cash holding and over-investment, J. Financial research. 7 (2009) 121-133.

9. Z. Huili, L. Zhengfei, The cash distribution, the corporate governance, and the over-investment: an investigation based on the state of the cash holdings of chinese listed companies and subsidiaries, J. Management world. 3 (2012) 141-188.

10. J. Coval, T. Moskowitz, Home bias at home: local equity preference in domestic portfolios, J. The Journal of Finance. 6 (1999 ) 2045-2073.

11. M. Hutchinson, M. Seamer, L. Chapple, Institutional investors, risk-performance and corporate governance, J. Int. J. Account. 50 (2015) 31-52.

12. B. S. Black, Agents watching agents: the promise of institutional investor voice, J. Social Science Electronic Publishing. 39 (1992) 811-893.

13. G. C. Biddle, G. Hilary and R. S. Verdi, How does financial reporting quality relate to investment efficiency, J. Journal of Accounting and Economics. 48 (2009) 112 131. 